\title{
AN ECONOMIC ANALYSIS OF THE MOST IMPORTANT FACTORS AFFECTING AGRICULTURAL GROWTH IN IRAQ USING ARDL MODEL
}

\author{
*H. A. Alattabi \\ Researcher \\ halaghaniss@gmail.com
}

\author{
B. H. AlBadri \\ Assist. Prof \\ College of Agricultural \\ Engineering Sciences/ \\ University of Baghdad \\ dr.basimbadri@yahoo.com
}

\begin{abstract}
This research was aimed to study some factors influencing agricultural growth in Iraq. Using time series data for the period 1990 - 2017, of agricultural growth (a dependent variable) and agricultural exports, agricultural imports, agricultural fixed capital and the agricultural labor force (as independent variables). For these purposes, were statistical and econometrics methods employed to determine the most important aspects of this problem in agricultural sector. Co-integration analysis was used which developed by Johansen, also Augmented Dicky - Fuller of unit root test to determine non stationary data for choosing the best analysis method. In light of results, Auto-Regressive Distributed Lag model (ARDL) was used in assessment and analysis. The results showed presence of co-integration in both agricultural imports and agricultural labor force with elasticity coefficients $(\mathbf{- 0 . 3}$ and-0.6), respectively and significant at $1 \%$ and $5 \%$ levels respectively, and lack of co-integration of both the agr.exports and agricultural fixed capital with elasticity coefficients ( 0.2 and 0.03$)$ respectively which they are not significant.
\end{abstract}

Keywords: agr.exports, agr.production, lag, stationary, co-integration.

*Part of M.Sc. thesis of the $1^{\text {st }}$ author.

العتابي والبدري

مجلة العلوم الزراعية العراقية -1570-1561:50:2019) مباقية

تحليل اقتصادي لأهم العوامل المؤثرة في النمو الزراعي في العرلق باستخدام أنموذج

$$
\text { هالة عبد الغني العتابي }
$$

المستخلص

استهف البحث دراسة أهم العوامل المؤثرة في النمو الزراعي في العرلق باستخدام بيانات سلسلة زمنية للمدة 1990 - 2017 وكان النمو الزراعي متغير تابع، وكل من الصادرات الزراعية، والاستيرادات الزراعية، ورأس المال الثابت الزراعي والقوى العاملة الزراعية كمتغيرات مستقلة. كما استُخدمت الأساليب الإحصائية والقياسية للوقوف على اهم جوانب هذا الموضوع في القطاع

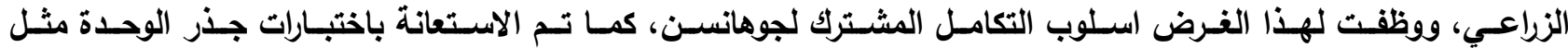
Augmented Dicky - Fuller لغرض الوقوف على استقرارية البيانات ومن ثم اختيار أسلوب التحليل الأمثل وصياغة الأنموذج القياسي. وعلى ضوء النتائج تم استخدام أنموذج Autoregressive Distributed Lag - ARDL في التقدير والتحليل، وأهم ما توصل اليه البحث هو وجود تكامل مشترك لكل من الاستيرادات الزراعية والقوى العاملة الزراعية في الأجل الطويل إذ بلغت معاملات المرونة (-0.3 و -0.6) على الترتيب وهي معنوية على (1\% و و5\%) على الترتيب، وغياب التكامل

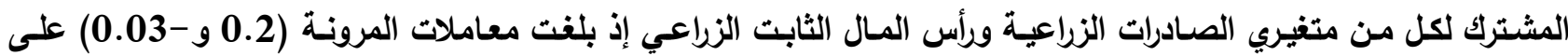
الترتيب وهي غير معنوية.

كلمات مفتاحية: صادرات زراعية، الناتج الزراعي، إبطاء، استقرارية، تكامل مشتركو.

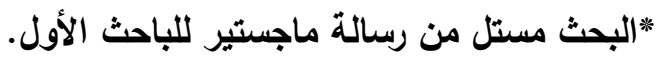

*Received:11/1/2019, Accepted:24/4/2019 


\section{INTRODUCTION}

Economic growth is concerned with the increasing susceptibility of an economy to the provision of goods and services over a certain period of time, whatever the source of such savings locally, externally or both (20). According to Pigou (English economist) the economic growth is "the amount of goods and services produced and placed at the disposal of individuals during a given period of time at lower costs, better quality and greater amounts than before" (6). Economic growth reflects quantitative changes in productive capacity and the extent to which this energy is exploited, the higher the utilization of available productive capacity and the level of all economic sectors, the higher the growth rates of domestic production and vice versa. Limitedness of the market is one of the main impediments to development, and it has become clear that the growth and increase of external demand for export products leads to the stimulation and channeling of investment in them to introduce better methods in the production and marketing of their products (4). It is natural that the rates of increase in domestic production cannot be maintained after the maximum utilization rate is attained and economic growth can be inferred by indicators (12): Determine the average real per capita income growth rates and determining real GDP growth rates or real net production. Although economic growth, and the resultant economic development, is the result of economic and other factors, its standards have become economic in nature without neglecting its other qualitative aspects, and this standards are based on macroeconomics indicators such as national income, distribution, per capita income, capital accumulation, and other indicators that include population growth, individual health, education and life expectancy, which are social in nature, i.e. they are not purely economic indicator. Economic growth is thus a process of constant and/or increase in a particular aspect of life. On the other hand, the world today, in the framework of a new global trading system, is witnessing many fluctuations, mainly due to complexity of economic life in hole world, due to expand and multiply business dealings, which led to the initiate economic clusters seek to lift out customs barriers and restrictions to international exchange based on the principle of specialization and division of Labor. Commercial laws have been established to ensure the good conduct of these trade exchanges. Over time the importance of economic international relationships has grown due high proportion of the foreign trade sector in production of countries and their economies in particular, this sector become a representative for the crucial and influential role of economic activity, and being considered as the most important images of economic relations under which goods and services are exchanged On form exports and imports, in addition to different production elements (especially labor and capital) between countries with a view to achieve mutual benefits for trade parties (5). Foreign trade is the engine of the foundation to economic growth in hole world. It expanded dramatically between countries because of the increase of production and easy transferring. And also because of the initiating of economic clusters and World Trade Organization. So, it is not possible isolate countries from each other because of reliance among them to provide goods and services by transfer surplus of theirs. Especially with major changes in foreign trade theories, and emergence of what known as new school of foreign trade, which focuses on the competitive advantages resulting from the economies of scale, diversification and distinct commodities rather than the comparative advantages resulting from the abundance of primary resources as the basis for the interpretation of contemporary foreign trade. There is a lack of information and no certainty of the nature of variables that effect of agr.growth in Iraq. Particularly the relationship between agr.exports and agr.growth (represented by growth rate in agr.production) in Iraq, so as to define appropriate agricultural policies, by mapping the comparative advantages of agricultural products (plant and animal) to identify the most important commodities that could be export commodities, thereby increasing their competitiveness and developing price intervention policies favourable to the domestic product for the purpose of increasing export surpluses. This research assumes that 
foreign trade in general and the Exports of agricultural products in particular in Iraq has a vital role in growth of the agricultural sector, which it means that they have a long-term cointegration relationship between agr.growth and foreign trade components, therefore we need to understand it and determine the nature and magnitude of this integration relation. Assessment and analysis Impact of (agr.exports, agr.imports, agricultural fixed capital and agricultural labor) in the growth of Agr.Production and its different influence on it, and estimate mathematical model that describe this relationship to determine the short-term and long-term relationships between them. It is necessary to take a quick and concise look at some of the previous studies that focused on the role of exports in economic growth, and point out to the results, in 2004 Awokuse studied the viability of the export hypothesis leads to growth in Canada, using the empirical evidence linking exports to economic growth, including Granger causality and Vector Error Correction Models (VECM) and applied Augmented Vector Auto Regressive (AVAR) methodology. The researcher used the natural logarithm of quarterly data for the period $(1961-2004)$, the study included the following variables in the model (gross domestic product, exports, trade rate, industrial employment, total capital formation, manufacturing index), and the study found a causal relationship in the short and long term between the variables in Canada confirms the validity of the Exports lead growth hypothesis (10). In 2007 Alhajhoj studied exports and economic growth in Saudi Arabia using VAR model, as well as the Immediate Response Function IFR, also verify the long-term causal relationship of the Granger test, using (gross domestic product, private consumption, government expenditure, investment, exports, imports, global growth rate). The study found three equations of cointegration and confirm that exports are causing growth, while the opposite is not true (3). In 2011 studied export - economic growth relationship represented by gross domestic product (GDP) In Algeria for the period 1970 - 2005, use co-integration method and ECM and using causality tests. He found that there was a co-integration among variables, and that exports caused growth in GDP in one-direction relationship (23). Faridi in 2012 studied the contribution of agr.exports to economic growth in Pakistan, in which the relationship between GDP as dependent variable, agricultural and non-agricultural exports as independent variables. Using Johansson cointegration analysis for the period (19722008), the results showed that agr.exports have a negative effect on economic growth, and that there is a two-way causal relationship for agr.exports and GDP (14). Ewetan and Okodua in 2013 studied the relationship between exports and economic growth in Nigeria (1970-2010), using co-integration analysis and the Granger causal test within the framework of a VAR model, and they have revealed that the model does not support the hypothesis that exports drive economic growth in Nigeria (13). Agrawal published a paper in 2014 about the role of exports in economic growth in India during the period of Indian trade liberalization (1960-2012), the analysis found that a positive causal link to the hypothesis of exports leads to growth, and the results showed that rapid growth in exports played an vital role in increasing of economic growth rate for the period after trade liberalization in India in 1991 (2). In 2014 Abu Shihab published a paper causal relationship between exports and economic growth in Jordan using the Granger cause methodology to determine the relationship trend for the period 2000 - 2012, the researcher used economic growth (GDP) and exports at current prices. She found a causal relationship from economic growth towards exports with significant level (0.15), and she accepted the existence of the first relationship at this level of signification (1). This research was aimed economic analysis of the most important factors affecting agricultural growth in Iraq using ARDL model.

\section{MATERIALS AND METHODES}

This study was relied on secondary data, which are the time series data covering the period from 1990 to 2017 obtained from local and global agencies such as:

- Ministry of Agriculture/ Iraq.

- Ministry of Planning/ Central Organization for Statistics and information Technology/ Iraq. 
- Iraqi Central Bank.

- Food and Agriculture Organization of the United Nations (FAO).

- World Trade Organization (WTO).

\section{Methods of analysis}

Applying of statistical and econometric methods on the time series in order to reach to the appropriate estimated model, which are:

1- Stationary test for time series.

2- Co-integration test.

3-Applying Auto-Regressive Distributed Lag Model (ARDL).

\section{stationary test of time series}

Before proceeding to study the fluctuations of any economic phenomenon, it is necessary to ascertain the existence of a trend (Trend) in the time series, depending on the nature of the growth of the chain, we can distinguish between stationary time series, non-stationary time series, and the fact that this series carries one of these situations has a direct relationship with the choice of a proper method. The stationary time series is that changes in its levels with no change in average over a relatively long period of time, i.e. the time series does not have a trend, either upward or downward. The unstable time series has a changing in average level (25). A time series is stationary if there are three characteristics available (18), (15):

a- Stability of the arithmetic means over time (constant mean): $\mathrm{E}\left(\mathrm{Y}_{\mathrm{t}}\right)=\mu$

b- Persistence of variation over time:(constant variance) $\operatorname{var}\left(\mathrm{y}_{\mathrm{t}}\right)=\delta^{2}$

c- The variance between any two values of the same variable depends on the time gap between the two values, and not on the actual value of time calculated at variance, i.e. the difference between two periods:

$\operatorname{cov}\left(\mathrm{y}_{\mathrm{t}}, \mathrm{y}_{\mathrm{t}+\mathrm{s}}\right)=\operatorname{cov}\left(\mathrm{y}_{\mathrm{t}}, \mathrm{y}_{\mathrm{t}-\mathrm{s}}\right)=\gamma_{\mathrm{s}}$

The time series stationary is verified by applying Augmented Dickey - Fuller (ADF) test (7):

$\Delta \mathrm{Y}_{\mathrm{t}} \quad=\quad \begin{array}{llll}\gamma & \mathrm{Y}_{\mathrm{t}-1} & + & \varepsilon_{\mathrm{t}}\end{array}$ $\Delta \mathrm{Y}_{\mathrm{t}}=\alpha_{0}+\gamma \mathrm{Y}_{\mathrm{t}-1}+\varepsilon_{\mathrm{t}}$ $\Delta \mathrm{Y}_{\mathrm{t}}=\alpha_{0}+\alpha_{1 \mathrm{t}}+\gamma \mathrm{Y}_{\mathrm{t}-1}+\sum \alpha_{\mathrm{j}} \Delta \mathrm{Y}_{\mathrm{t}-\mathrm{j}+1}+\varepsilon_{\mathrm{t}}$

Where they represent $\Delta$ the first difference, $y$ tested variable, $\varepsilon_{\mathrm{t}}$ error term, the most important parameter is $\gamma$ Where $\gamma=\alpha_{\mathrm{I}-1}$, If $=0$ This means that $y_{t}$ contain the unit root. Obviously, the difference among the previous three equations are the presence or absence of one of the two parameters $\alpha_{0} \& \alpha_{1 t}$ or both. the first equation, not include either of them, while the $\alpha_{0}$ added to represent the constant in the second equation, and in the third equation we added the constant and the trend. The test is based on significant of $t$ of the coefficient of the dependent variable $\mathrm{y}_{\mathrm{t}-1}$, where critical values are compared to calculated values from the test, If the value that calculated (the absolute value) bigger than the critical value, that extracted from the table of Mackinnon we reject the null hypothesis that there is a unit root, and then accept the alternative hypothesis, which means that time series stationary at level $\mathrm{I}(0)$.

\section{Co-integration Test}

This test is conducted to identify the possibility of an integration relationship of variables covered by the study in the long term. The co-integration analysis focuses on the behavior of residuals. There are several ways to detect a co-integration of which test Angel-Granger test, Johansson test. As for cointegration that is extracted from the ARDL model an implicit procedure for exhibiting qualifies us to study the long-term relationship between two specific variables with different integration levels, which will be used later (26), (11).

\section{Auto-regressive distributed lag model (ARDL)}

In the building of economic models, it is important to keep in mind the lag of time series, since there is usually a time period between the movement of dependent variables that respond to the independent variables. The introduction of such variables in the regression analysis makes the analysis more comprehensive and closer to reality. There are variables may be linked to other variables in the same period of time called static models, and in most cases may be linked to the past values of some variables, the models become a dynamic. So, the lagged variable of the independent variable should be presented, because in the time series models there is a particular time period between the economic decision and the final effect of the change economic policy variable, especially in a long term. The time lagged variable is necessary in economy, affecting the methods of economic analysis, both in the short or long term (27). 
As a result of the behavior of model variables for different behavior in terms of stationary and lag times, we use the Autoregressive Distributed Lag (ARDL) model, which corresponds to this type of variation. As discussed above, the ARDL model means the Auto-regression of $y_{t}$, and DL means that the dependent variable will be described by his own lagged period or the lagged of independent variables (15).

Evolution of model variables in Iraqi agricultural sector during the period 1990 2017

Iraq has undergone two phases, both economically and politically differ, during the period studied. The first phase from 1990 to 2002, which Iraq was subjected to economic sanctions by the United Nations, which is a critical phase in the Iraqi economy general and exports in particular, including agricultural exports. Second phase from 2003 to 2017 which include the invasion of Iraq by collision forces, that caused a disturbing reaction in economic life. Table 1 shows annual and compound growth rate for our model variables. agr.exports growth rate is $(3.38 \%)$, while the agr.exports compound growth rate was $(-8.85 \%)$. This is due to the significant decline in the value of agr.exports in Iraq during the period of economic sanctions.

Table 1. Annual and compound growth rate in Iraq 1990 - 2017

\begin{tabular}{|ccc|}
\hline & $\begin{array}{c}\text { Annual } \\
\text { Growth rate }\end{array}$ & $\begin{array}{c}\text { Compound Growth } \\
\text { Variables }\end{array}$ \\
& $\%$ & $\%$ \\
\hline Agr.Exports & 3.38 & -8.85 \\
Agr.Production & 11.12 & 6.6 \\
Agr.Imports & 11 & 2.6 \\
Agricultural fixed capital & 11.3 & 6.2 \\
Agr.Labor & 2.4 & 6.7 \\
\hline
\end{tabular}

Source:

- Central Organization for Statistics and information Technology

- Data of Iraqi Central Bank

- Statistics FAO web-based organization (faostat), www.fao.org/faostat/.

Iraq's exports of agricultural products are food products, dates (mainly), meat, leather and deferent types of wool, dairy products, eggs, cereals and sugar, and all under (Standard International Trade Classification - SITC). But the imposition of economic sanctions on Iraq in 1990s has significantly reduced agr.exports as part of the country's economic system. As example the value of agr.exports in 1990 was (251.7) million US dollar, and it declined in 1991 to until reach 9.8 million US dollars with an annual change of (-96\%).

\section{Augmented Dicky - Fuller (ADF) unit root test}

The results show that almost all variables are non-stationary on the level $\mathrm{I}(0)$, which means there is a trend effect with all variables. After applying the first deference I(1) the data were stable, so we could proceed further to the next step which is the formulation of the mathematical model. 
Table 2. ADF stationary test results at $I(0)$ and $I(1)$

\begin{tabular}{|c|c|c|c|c|c|c|}
\hline \multicolumn{2}{|l|}{ At Level } & LOG (A) & LOG (E) & LOG (M) & LOG (F) & LOG (L) \\
\hline \multirow[b]{2}{*}{ With Constant } & t-Statistic & -0.6095 & -2.6333 & -1.6774 & -2.5111 & -0.3352 \\
\hline & Prob. & $\begin{array}{c}\mathbf{0 . 8 5 2 6} \\
\text { No }\end{array}$ & $\begin{array}{c}0.0994 \\
*\end{array}$ & $\begin{array}{c}0.4309 \\
\text { No }\end{array}$ & $\begin{array}{c}0.1240 \\
\text { No }\end{array}$ & $\begin{array}{c}0.9060 \\
\text { No }\end{array}$ \\
\hline \multirow[b]{2}{*}{$\begin{array}{c}\text { With Constant } \\
\text { \& Trend }\end{array}$} & t-Statistic & -2.5162 & -3.1858 & -3.3578 & -4.1166 & -3.2984 \\
\hline & Prob. & $\begin{array}{c}\mathbf{0 . 3 1 8 3} \\
\text { No }\end{array}$ & $\begin{array}{c}0.1090 \\
\text { No }\end{array}$ & $\begin{array}{c}\mathbf{0 . 0 7 8 5} \\
*\end{array}$ & $\underset{* *}{\mathbf{0 . 0 1 6 4}}$ & $\begin{array}{c}\mathbf{0 . 0 8 7 9} \\
*\end{array}$ \\
\hline \multirow{2}{*}{$\begin{array}{c}\text { Without Constant } \\
\text { \& Trend }\end{array}$} & t-Statistic & 1.1793 & -1.4739 & -0.1400 & -0.4999 & 0.9665 \\
\hline & Prob. & $\begin{array}{c}\mathbf{0 . 9 3 4 5} \\
\text { No }\end{array}$ & $\begin{array}{c}\mathbf{0 . 1 2 8 5} \\
\text { No }\end{array}$ & $\begin{array}{c}\mathbf{0 . 6 2 6 2} \\
\text { No }\end{array}$ & $\begin{array}{c}\mathbf{0 . 4 9 0 2} \\
\text { No }\end{array}$ & $\begin{array}{c}0.9064 \\
\text { No }\end{array}$ \\
\hline \multicolumn{2}{|c|}{ At First Difference } & D (LOG (A)) & D (LOG $(E))$ & D (LOG (M)) & D (LOG (F)) & D (LOG (L)) \\
\hline \multirow[b]{2}{*}{ With Constant } & t-Statistic & -7.3904 & -5.8700 & -6.8351 & -6.9791 & -6.6677 \\
\hline & Prob. & $\begin{array}{c}\mathbf{0 . 0 0 0 0} \\
* * *\end{array}$ & $\begin{array}{c}\mathbf{0 . 0 0 0 1} \\
* * *\end{array}$ & $\underset{* * *}{\mathbf{0 . 0 0 0 0}}$ & $\begin{array}{c}\mathbf{0 . 0 0 0 0} \\
* * *\end{array}$ & $\begin{array}{c}\mathbf{0 . 0 0 0 0} \\
* * *\end{array}$ \\
\hline \multirow{2}{*}{$\begin{array}{c}\text { With Constant } \\
\text { \& Trend }\end{array}$} & t-Statistic & -7.2533 & -5.7490 & -6.6558 & -6.8341 & -6.6832 \\
\hline & Prob. & $\begin{array}{c}\mathbf{0 . 0 0 0 0} \\
* * *\end{array}$ & $\underset{* * *}{\mathbf{0 . 0 0 0 5}}$ & $\underset{* * *}{0.0001}$ & $\underset{* * *}{0.0000}$ & $\underset{* * *}{0.0001}$ \\
\hline \multirow{2}{*}{$\begin{array}{c}\text { Without Constant } \\
\text { \& Trend }\end{array}$} & t-Statistic & -1.5974 & -5.9629 & -6.8803 & -7.0692 & -6.6031 \\
\hline & Prob. & $\begin{array}{c}0.1022 \\
\text { No }\end{array}$ & $\begin{array}{c}\mathbf{0 . 0 0 0 0} \\
* * *\end{array}$ & $\begin{array}{c}\mathbf{0 . 0 0 0 0} \\
* * *\end{array}$ & $\begin{array}{c}\mathbf{0 . 0 0 0 0} \\
* * *\end{array}$ & $\begin{array}{c}\mathbf{0 . 0 0 0 0} \\
* * *\end{array}$ \\
\hline
\end{tabular}

*: significant at $10 \%$

Source: output of Eviews 10 program

\section{Formulation of the mathematical model}

The choice of independent variables that influencing the dependent variable (the growth in agricultural product) is determined by a combination of factors including the concepts of economic theory and studies in this field as well as the property of the local economy. The mathematical model of the method is characterized as ARDL for the time series from 1990 to 2017 to include* :

$\Delta \log A=\beta_{0}+\sum_{i=1}^{k} \beta_{1} \log A_{t-i}+$

$\sum_{i=0}^{k} \beta_{2} \log E_{t-i}+\sum_{i=0}^{k} \beta_{3} \log M_{t-i}+$

$\sum_{i=0}^{k} \beta_{4} \log F_{t-i}+\sum_{i=0}^{k} \beta_{5} \log L_{t-i}+$

$\varphi_{1} Y_{t-1}+\varphi_{2} E_{t-1}+\varphi_{3} M_{t-1}+\varphi_{4} F_{t-1}+$

$\varphi_{5} L_{t-1}+\varepsilon_{i}$

Where:

$\Delta \log \mathrm{A}=$ The first difference of the logarithm of agr.production and represents growth rate $\log \mathrm{E}=$ Logarithm of agr.exports in million Iraqi Dinar

$\log M=$ Logarithm of agr.imports in million Iraqi Dinar

$\log \mathrm{F}=$ Logarithm of agricultural fixed capital million Iraqi dinar

$\log \mathrm{L}=$ Logarithm of agricultural labor in thousand persons.

$K=$ Number of lags

$\beta=$ Short-run coefficients

$\varphi=$ Long-run coefficients

* The first difference to the logarithm of any variable $\left(Y_{t}\right)$ represents the growth rate of this variable: $\Delta \log (\mathbf{y}) \approx\left(\mathbf{Y}_{\mathrm{t}}-\mathbf{Y}_{\mathrm{T}-1}\right) / \mathbf{Y}_{\mathrm{T}-1}$, shown in (17), (19), (28). $\varepsilon \mathrm{i}=$ Error term

\section{Johansen and Juselius co-integration}

The test Johansen and Juselius of cointegration test uses both Trace test and Full Information Maximum Likelihood, in case of multiple variables, all variables are treated as internal variables, indicating whether there is a long-term relationship or not. Because we have four internal independent variables which indicate that we have more than one vector for co-integration among them (9)

1- Trace test is calculated in the following equation:

$$
\lambda_{\text {trace }}(r)=-T \sum_{i=r+1}^{n} \ln \left(1-\lambda_{r+1}^{\wedge}\right)
$$

Where T: Sample size, r: Number of cointegration vectors.=

The null hypothesis states that there are a number of co-integration integers at most equal to $r$, which mean the number of these vectors $\leq \mathrm{r}$.

2- Maximum eigen values test is calculated in the following form:

$$
\lambda_{\max }(r, r+1)=-T \ln \left(1-\lambda_{r+1}\right)
$$

Null hypothesis test, which provides for the existence of co-integration vectors versus the alternative hypothesis that provides $r+1$ of the co-integration vectors. If the calculated value of the potential ratio exceeds the critical value at a certain level, we reject the null hypothesis that indicates no co-integration. 


\section{RESULTS AND DISCUSSION}

The results were coming to reject null hypothesis and acceptance of the alternative hypothesis based on the coefficient of trace (88.3), which is greater than the critical value of null hypothesis of (69.8) at a significant level of $5 \%$, which confirms the existence of one co-integration as in table (3). The test of Max - Eigen value is (45.04), and its higher than the critical value (33.87) of null hypothesis (27.6). And At most1 reached to (27.6) which is higher than the critical value (27.58) at 5\% level of significant. Thus, we reject the null hypothesis of non-existence of co-integration and accept the alternative hypothesis that there is more than one equation for the co-integration of this test. -

Table 3. Trace and Max-Eigen Tests

\begin{tabular}{|c|c|c|c|c|c|c|c|}
\hline \multicolumn{4}{|c|}{ Unrestricted Cointegration Rank Test (Trace) } & \multicolumn{4}{|c|}{$\begin{array}{c}\text { Unrestricted Cointegration Rank Test } \\
\text { (Maximum Eigenvalue) }\end{array}$} \\
\hline $\begin{array}{l}\text { Hypothesized } \\
\text { No. of CE (s) }\end{array}$ & $\begin{array}{c}\text { Trace } \\
\text { Statistic }\end{array}$ & $\begin{array}{c}0.05 \\
\text { Critical Value }\end{array}$ & Prob. ** & $\begin{array}{l}\text { Hypothesized } \\
\text { No. of CE (s) }\end{array}$ & $\begin{array}{l}\text { Max-Eigen } \\
\text { Statistic }\end{array}$ & $\begin{array}{c}0.05 \\
\text { Critical Value }\end{array}$ & Prob. ** \\
\hline None & 88.34315 & 69.81889 & 0.0008 & None & 45.04719 & 33.87687 & 0.0016 \\
\hline At most 1 & 43.29596 & 47.85613 & 0.1255 & At Most $1 *$ & 27.64166 & 27.58434 & 0.0492 \\
\hline At Most 2 & 15.65430 & 29.79707 & 0.7363 & At Most 2 & 9.195915 & 21.13162 & 0.8163 \\
\hline At Most 3 & 6.458388 & 15.49471 & 0.6413 & At Most 3 & 5.610485 & 14.26460 & 0.6635 \\
\hline At Most 4 & 0.847902 & 3.841466 & 0.3571 & At Most 4 & 0.847902 & 3.841466 & 0.3571 \\
\hline \multicolumn{4}{|c|}{$\begin{array}{l}\text { Trace test indicates } 1 \text { cointegrating eqn }(s) \text { at the } \\
0.05 \text { level }\end{array}$} & \multicolumn{4}{|c|}{$\begin{array}{l}\text { Max-eigenvalue test indicates } 2 \text { cointegrating eqn (s) at } \\
\text { the } 0.05 \text { level }\end{array}$} \\
\hline
\end{tabular}

Source: outputs of Eviews 10 program Estimation using ARDL model

Several attempts were made to obtain the best and most discretionary results in terms of their conformity with the criteria and the absence of problems and others, and the results mentioned in table (4). The results have shown the choice of formula (2.0.2.2.1), which represents the short-term function, means two slowdowns of the variable of agr.production growth, the nonlag of the variable of agr.exports, the one lag of both agr.imports and agricultural fixed capital,

Table 4. ARDL Model

\begin{tabular}{|c|c|c|c|c|c|c|c|}
\hline Variable & Coefficient & t-Statistic & Prob. * & Variable & Coefficient & t-Statistic & Prob. * \\
\hline D (LOG)A-1)) & -0.400256 & -2.366937 & 0.0341 & LOG (F) & -0.011462 & -0.311675 & 0.7602 \\
\hline D (LOG)A-2)) & -0.284314 & -1.650481 & 0.1228 & LOGF-1)) & 0.082644 & 1.766522 & 0.1008 \\
\hline LOG (E) & 0.038378 & 0.587844 & 0.5667 & LOGF-2)) & -0.116118 & -3.381417 & 0.0049 \\
\hline LOG (M) & -0.024614 & -0.392303 & 0.7012 & LOG (L) & -0.563114 & -1.847012 & 0.0876 \\
\hline LOGM-1)) & 0.218269 & 2.601331 & 0.0220 & LOGL-1)) & -1.143566 & -3.532283 & 0.0037 \\
\hline LOGM-2)) & 0.168775 & 2.750886 & 0.0165 & $\mathrm{C}$ & 10.07481 & 3.972966 & $\mathbf{0 . 0 0 1 6}$ \\
\hline \multicolumn{2}{|c|}{ R-squared } & 0.720656 & & \multicolumn{2}{|c|}{ Mean dependent Var } & \multicolumn{2}{|c|}{0.070003} \\
\hline \multicolumn{2}{|c|}{ Adjusted R-squared } & 0.484287 & & \multicolumn{2}{|c|}{ S.D. dependent Var } & \multicolumn{2}{|c|}{0.225326} \\
\hline \multicolumn{2}{|c|}{ S.E. of regression } & 0.161814 & & \multicolumn{2}{|c|}{ Akaike Info criterion } & \multicolumn{2}{|c|}{-0.498670} \\
\hline \multicolumn{2}{|c|}{ Sum Squared Resid } & 0.340387 & & \multicolumn{2}{|c|}{ Schwarz criterion } & \multicolumn{2}{|c|}{0.086390} \\
\hline \multicolumn{2}{|c|}{ Log likelihood } & 18.23338 & & \multicolumn{2}{|c|}{ Hannan-Quinn Criter. } & \multicolumn{2}{|c|}{-0.336399} \\
\hline \multicolumn{2}{|c|}{ F-statistic } & 3.048869 & & \multirow{2}{*}{\multicolumn{2}{|c|}{ Durbin-Watson Stat }} & \multirow{2}{*}{\multicolumn{2}{|c|}{2.406206}} \\
\hline $\operatorname{Prob}(\mathbf{F}$ & tic) & 0.029848 & & & & & \\
\hline
\end{tabular}

\section{Source: outputs of Eviews 10 program}

The results table 4 shows the results of the impact of independent variables with their lags on the dependent variable, as well as the effect of dependent variable lag itself. Showing that the value of the $R^{2}$ was $(0.72)$, which means that $72 \%$ of fluctuations in the dependent variable (growth in agricultural products) were caused by variables in the model, and that $(28 \%)$ of fluctuations not included in the model or have absorbed the error term. As it turns out that the statistic value $\mathrm{F}$ reached (3.04) and it is significant at the level of (5\%). $\mathrm{D}-\mathrm{W}$ as it is known, it is unreliable because of the lag of the dependent variable itself in the estimation, so we replaced it with BreuschGodfrey LM (The Lagrange multiplier test) to detect the auto-correlation problem.

ARDL Model Tests : In order to determine the characteristics of the mathematical model, the researcher has to perform several tests and as follows:

\section{a- Breusch-Godfrey of auto-correlation test}

One of the most important tests in this field is the serial auto-correlation test for the error term in the model using the Lagrange multiplier test (LM test) developed by Breusch And Godfrey in 1978, the results confirmed 
the lack of auto-correlation by comparing the probability of a statistic Chi-Square of 0.21 and it greater than 0.05 . We accept the null hypothesis, meaning that the model is good and there is no serial auto-correlation of errors in it.

Table 5, Lagrange multiplier test $\mathrm{Lm}$

\begin{tabular}{|llll|}
\hline F-statistic & $\mathbf{0 . 7 6 1 1 6 4}$ & Prob. F(2, 11) & $\mathbf{0 . 4 9 0 2}$ \\
\hline $\begin{array}{l}\text { Obs * R- } \\
\text { squared }\end{array}$ & $\mathbf{3 . 0 3 9 2 2 9}$ & $\begin{array}{l}\text { Prob. Chi- } \\
\text { Square(2) }\end{array}$ & $\mathbf{0 . 2 1 8 8}$ \\
\hline
\end{tabular}

\section{Source: outputs of Eviews 10 program}

\section{b- Bound Test}

F test value was (7.63), which is significant at level $1 \%$, and as shown in table (6), when compared with tables prepared for this purpose by the economist Pesaran. The test has an upper and lower limit and if the value of $\mathrm{F}$ is greater than the upper limit at $1 \%$ level of significant which is (4.37). So, we reject the hypothesis of not having a long relationship. We reject the null hypothesis that there is no long-term relationship between the explanatory variables and the dependent variable and accept the alternative hypothesis.

Table 6. Bound Test

\begin{tabular}{|ccccc|}
\hline Test Statistic & Value & Signif. & I0 & I1 \\
\hline F-statistic & $\mathbf{7 . 6 3 0 2 1 0}$ & $\mathbf{1 0}$ & $\mathbf{2 . 2}$ & $\mathbf{3 . 0 9}$ \\
k & 4 & 5 & $\mathbf{2 . 5 6}$ & $\mathbf{3 . 4 9}$ \\
& & 2.5 & 2.88 & 3.87 \\
& & 1 & 3.29 & 4.37 \\
\hline
\end{tabular}

Source: outputs of Eviews 10 program

\section{c- Heteroskedasticity Test}

Based on the Breusch-Pagan-Godfrey (BPG) test, $F$ value was (0.59). The results of Heteroskedasticity test on the model showed that the value of the Chi-Square statistic was (0.68). Therefore, there is no difference in variance of error term and thus acceptance of null hypothesis, which means, there is no problem of consistency instability of the variance of the model.

Table 7, Heteroskedasticity test

\begin{tabular}{|cccc|}
\hline F-statistic & $\mathbf{0 . 5 9 3 4 8 1}$ & Prob. F(11, 13) & $\mathbf{0 . 8 0 3 7}$ \\
\hline $\begin{array}{c}\text { Obs * R-squared } \\
\text { Scaled explained } \\
\text { SS }\end{array}$ & $\mathbf{8 . 3 5 7 4 7 6}$ & $\begin{array}{c}\text { Prob. Chi- } \\
\text { Square11 } \\
\text { Prob. Chi- } \\
\text { Square11 }\end{array}$ & $\mathbf{0 . 6 8 1 0}$ \\
\hline
\end{tabular}

Source: outputs of Eviews 10 program

d- Co-integration test by testing the stationary of residuals of model : We performed co-integration test to ensure a longterm integration relationship among variables, and that by testing the stationary of residuals using ADF and PP tests. The results show that the residuals are stationary at $1 \%$ level of significant as showed in table 8 . So, we reject the null hypothesis that there is a unit root in the series and accept the alternative hypothesis that there is no unit root, which indicates a long-term co-integration relationship.

Table 8. Unit root test of residuals at $\mathbf{I}(0)$

\begin{tabular}{|cccc|}
\hline & & ADF & PP \\
\hline & t-Statistic & $\mathbf{- 6 . 1 2 6 8}$ & $\mathbf{- 6 . 2 2 5 3}$ \\
With Constant & Prob. & $\mathbf{0 . 0 0 0 0}$ & $\mathbf{0 . 0 0 0 0}$ \\
& & $* * *$ & $* * *$ \\
& t-Statistic & $-\mathbf{5 . 9 5 1 1}$ & $-\mathbf{6 . 0 3 7 5}$ \\
With Constant & Prob. & $\mathbf{0 . 0 0 0 3}$ & $\mathbf{0 . 0 0 0 3}$ \\
\& Trend & & $* * *$ & $* * *$ \\
& t-Statistic & $-\mathbf{- 6 . 2 4 9 7}$ & $-\mathbf{- 6 . 3 4 1 8}$ \\
Without Constant & Prob. & $\mathbf{0 . 0 0 0 0}$ & $\mathbf{0 . 0 0 0 0}$ \\
\& Trend & & $* * *$ & $* * *$ \\
\hline
\end{tabular}

***:significant $1 \%$ level

Source: outputs of Eviews 10 program.

e- cusum, cusumsq of stability test

The cumulative total Cusum and the Cusumsq of the model structural stability tests are in the short and long term. the structural stability of the estimated ARDL model achieved if the trend of each statistic is coming within the critical limits at 5\% level of significant, these trends are unstable if the graph of the abovementioned tests is moved out of bounds at this level. The results show a structural stability among the study variables and the compatibility of the two prototypes in the short and long term, as in figure (1).

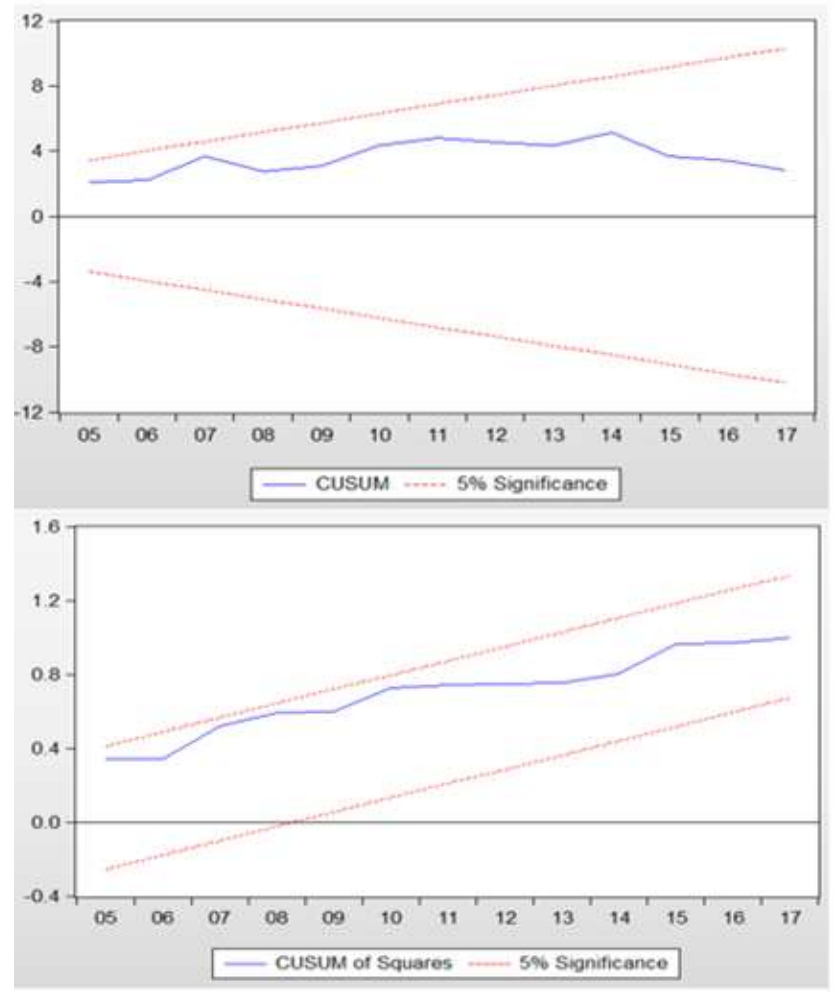

Fig 1. Cusum and Cusumsq stability test Source: outputs of Eviews 10 program 
Long-term equation within the estimated model: The results in Table 9 shows long-term equation or the co-integration between the independent variables and dependent variable, the signal of $\log (\mathrm{E})$ comes positive (0.02) but not significant, which state to lack of cointegration or the long-term relationship between agr.exports and agr.growth, which is meat with the results of the relative importance of agr.exports as compared to the average agr.production (1.73\%), and $(0.5 \%)$ as compared with total export at average. $\log (\mathrm{M})$ With a value of $(0.22)$ and $1 \%$ significant to indicate a long-term relationship between them, either variable $\log (\mathrm{F})$ It has a value of (0.02 ) but it is not significant as an indicator of the independence between the two variables and the lack of co-integration between agricultural fixed capital and agr.growth. The coefficient of labor force in the agricultural sector was (-1.01), and it significant at $1 \%$, which is an indication of a strong long-term relationship between them, but increase in the work does not necessarily mean an increase in agr.growth and this result means that there is more labor surplus than the planned, and that increase in number of workers in front of steady level of growth, which means that there are a lot of workers within the agricultural sector and they have no work and this is called disguised unemployment or even seasonal unemployment, or because the labor force lacks the required efficiency of being unskilled and untrained, therefore their productivity are weak.

Table 9. long term equation

\begin{tabular}{|ccccc|}
\hline Variable & Coefficient & Std. Error & t-Statistic & Prob. \\
\hline LOG (E) & $\mathbf{0 . 0 2 2 7 8 2}$ & $\mathbf{0 . 0 3 8 5 8 9}$ & $\mathbf{0 . 5 9 0 3 8 1}$ & $\mathbf{0 . 5 6 5 1}$ \\
LOG (M) & $\mathbf{0 . 2 1 5 1 4 7}$ & $\mathbf{0 . 0 5 6 8 6 7}$ & $\mathbf{3 . 7 8 3 3 1 2}$ & $\mathbf{0 . 0 0 2 3}$ \\
LOG (F) & $\mathbf{- 0 . 0 2 6 6 7 6}$ & $\mathbf{0 . 0 2 1 8 3 7}$ & $\mathbf{- 1 . 2 2 1 5 7 7}$ & $\mathbf{0 . 2 4 3 6}$ \\
LOG (L) & $\mathbf{- 1 . 0 1 3 1 2 5}$ & $\mathbf{0 . 2 5 2 1 1 1}$ & $-\mathbf{4 . 0 1 8 5 7 3}$ & $\mathbf{0 . 0 0 1 5}$ \\
C & $\mathbf{5 . 9 8 0 6 4 8}$ & $\mathbf{1 . 5 0 9 5 3 1}$ & $\mathbf{3 . 9 6 1 9 2 4}$ & $\mathbf{0 . 0 0 1 6}$ \\
\hline
\end{tabular}

Source: outputs of Eviews 10 program

Notice that negative sign of some independent variables or nonsignificant of others are only a reflection of the real situation in Iraq, particularly the impact of agr.exports on agr.growth during the period of study or longterm co-integration that they have.We can extract group of conclusions that carry the answer to the problem of research, and test hypothesis that have been put forward and we include: An overall decline in growth of agr.exports during the period of the study. This may be due to the lack of an export strategy for agricultural products, the lack of a specialized institution care of developing Iraq's agr.exports and supporting agricultural exporters، as well as the lack of a map of comparative advantages of agricultural products. In the light of the results obtained from the mathematical model, there is no co-integration relationship in the short and long term between the agr.exports and the agr.growth in Iraq during the period studied, and maybe due to the small value of agricultural exports relative to agricultural output and impact of political and security conditions and devaluation of the currency compared with the US dollar, which was reflected in agricultural production and consequently agricultural exports. If agr.growth that related to unstable revenue, the agr.growth that comes from real increase in production is able of support agr.exports growth. Also, can contribute to stable economic growth and sustainable. So, we need to encourage the investment in the agriculture sector by facilitating and simplifying procedures for the granting of export licenses included (Certificate of origin, health safety certificate, etc.) to promote agricultural investment and to achieve the development of agr.products in Iraq.

\section{REFRENCES}

1. Abu Shihab, R., T. Soufan and S. AbdulKhaliq, 2004, The causal relationship between exports and economic growth in Jordan, global journal of management and business research: B, Economics and Commerce, 14 (3): 17-22

2. Agrawal, P., 2014, The Role of exports in India's economic growth, IEG Working Paper No: 345.

3. Alhajhoj, H, 2007, Exports and economic growth in Saudi Arabia: A VAR model analysis, Journal of Applied Science 7 (23): 3649-3658

4. Al-Jubori, Y. Y. and B. H. Al-Badri, 2017, Gravity model in foreign trade (applicable case about the skins in Iraq during the period 1990 - 2014), Iraqi Journal of Agricultural Sciences, 48 (4):1032-1039

5. Al-Shafei, M. Z., 1968, Economic Development, Arab Renaissance House, Cairo, pp: 157 
6. AL-Sid Ali, A., 1984, Introduction to Economics, Part II, National Library, Baghdad, pp: 121

7. Al-Sid Hashim, A., A. Abu Alyazid, M. Abdel Hadi and S. Mohamed, 2015, The role of agr.exports in agricultural economic growth in Egypt (standard study), Alexandria Journal of Scientific Exchange 36 (4): 616 - 630

8. Al-Sonbol, E. A., 2002, Economic Growth and Structural Changes in the Iraqi Agricultural Economy for the Period (1970 1999), Ph.D. Dissertation, Department of Agricultural Economics/ College of Agriculture, University of Baghdad, pp: 15-18 9. Al-Taie, A. O. and M. S. Alshammary, 2014, Analysis the Factors of the Exchange Rate Effect on the General Price Level Using the Causal Model in Iraq for The Period (1990 - 2011), Algerri Journal of Economic and Administrative Sciences, year $10^{\text {th }}-8(31)$ : 40 55

10. Awokuse, T. O., 2004, Is the export-led growth hypothesis valid for Canada? Canadian Journal of Economics, 36(1): 126 - 136

11. Dritsakis, N., 2011, Demand for Money in Hungary: An ARDL Approach, Academic Research Centre of Canada, 1: 01-16

12. Erekat, M. H. , 1998, Introduction to Development and Economic Planning, Dar Wael, Jordan, second edition, pp: 76

13. Ewetan, O., and H. Okodua, 2013, Econometric analysis of export and economic growth in Nigeria, Journal of Business Management and Applied Economics, 2 (3): 114

14. Faridi, M. Zahir, 2012, Contribution of agr.exports to economic growth in, Pakistan, Pakistan Journal Commercial Social Science, 6 (1): 133-146.

15. Hill, R., Griffiths, and W., G. Lim, 2011, Principles of Econometrics, Fourth edition, John Wiley \& Sons, pp:477

16. Johnston, B. F. and M. W. John, 1961, The Role of Agriculture in Economic Development, Published by: American Economic Association, Stable URL: http://www.jstor.org/stable/1812786

17. Johnston, J., and D. John, 1996, Econometric Methods, McGraw-Hill/Irwin; $4^{\text {th }}$ ed, pp: 43

18. Jubair, B. N. and A. D. K. Al-Hiyali, 2018, An economic study of the impact of foreign agricultural trade and some macroeconomic variables on the exchange rate in Iraq using the FMOLS model for the period 1990 - 2015, Iraqi Journal of Agricultural Sciences :49(4):142- 110

19. Kirchgässner, G., and Jürgen Wolters, 2007, Introduction to Modern Time Series Analysis, Springer Berlin Heidelberg New York, pp: $7-11$

20. Maarouf, H., 2005, Macro-Economic Analysis, Safa for Publishing and Distribution, Amman, pp: 347

21. Matsuyama, K., 1992, Agricultural productivity, comparative advantage, and economic growth, Journal of Economic Theory, pp: 317-334

22. Meijerink, G. and P. Roza, 2014, The role of agriculture in economic development, Markets, Chains and Sustainable Development Strategy \& Policy Papers, Available online at: http://www.boci.wur.nl/UK/Publications/.

23. Meqran, B., 2011, The Relationship of Exports to Economic Growth During the Period (1970 - 2005), M.Sc. Thesis, University of Algeria, Faculty of Economics and Management Sciences/ Department of Economics, pp: 10

24. Mohieddin, A., 1975, Underdevelopment and Development, Dar Al-Nahda Arabia Printing and Publishing, Beirut, pp: 231

25. Muhammed .R. F. and A. D. K. Al-Hiyali. 2018, Estimation of the impact of some variables of agricultural policy on the Iraqi domestic agricultural product for the period 1994 - 2015 using the method of cointegration and the ARDL model, Iraqi Journal of Agricultural Sciences, 49(6):101-128

26. Parente, S. L., 2002, The Role of Agriculture in Development, Article in American Economic Review, published on https://www.researchgate.net/publication/4726 $\underline{819}$

27. Sheikhi, M., 2011, Econometric Methods Lectures and Applications, University of Wargla, Dar al-Hamid, Algeria, $1^{\text {st }}$ ed, pp: 201 28. Wooldridge, J., M., 2015, Introductory Ecnometers $\backslash$ A Modern Approach, Cengage Learning, WCN: 02-200-203, USA., $6^{\text {th }}$ ed, pp: 366. 